\title{
ANALISIS HAMBATAN GURU IPS DALAM PEMBELAJARAN JARAK JAUH DAMPAK PANDEMI COVID-19 DI SMP/MTS KECAMATAN GEBOG KABUPATEN KUDUS
}

\author{
Naila Ferdianita, Ferani Mulianingsih ${ }^{凶}$ \\ Prodi Pendidikan Ilmu Pengetahuan Sosial, Fakultas Ilmu Sosial, Universitas Negeri Semarang, Indonesia
}

\section{Info Artikel}

Sejarah Artikel:

Disubmit: Januari 2021

Direvisi: Februari 2021

Diterima: Maret 2021

\section{Keywords:}

Social Studies Teacher,

Distance Learning (PJJ),

Covid-19 Pandemic,

Barriers to learning.

\begin{abstract}
Abstrak
Penelitian ini bertujuan untuk mengetahui hambatan guru IPS dalam pembelajaran jarak jauh (PJJ) di Kecamatan Gebog Kabupaten Kudus. Hasil analisis menunjukan adanya pandemi covid-19 menjadikan pembelajaran di Kecamatan Gebog Kabupaten Kudus dilakukan dengan pembelajaran jarak jauh (PJJ). Hambatan guru IPS dalam pembelajaran jarak jauh (PJJ) meliputi; (1) perbedaan letak geografis, (2) keterbatasan sarana prasarana pembelajaran, (3) peserta didik pasif, (4) penilaian pembelajaran, (5) kuota belajar yang besar, (6) kemampuan profesional guru. Dan upaya dalam mengatasi hambatan pembelajaran jarak jauh (PJJ) meliputi; (1) kebijakan masingmasing sekolah, (2) pemberian tugas dilakukan secara langsung (3) pemberian motivasi belajar dan school visit, (4) pemberian kuota belajar dari pemerintah, (5) pengumpulan tugas secara langsung, (6) peningkatan kemampuan profesional guru dalam penggunaan teknologi dan komunikasi.
\end{abstract}

\begin{abstract}
This study aims to determine the barriers of IPS teachers in distance learning (PJJ) in Gebog District, Kudus Regency. The results of the analysis show that the covid-19 pandemic makes learning in Gebog District, Kudus Regency done with distance learning (PJJ). IPS teacher barriers in distance learning (PJJ) include; (1) differences in geographical location, (2) limitations of learning infrastructure, (3) passive learners, (4) learning assessment, (5) large learning quota, (6) teacher professional ability. And efforts in overcoming distance learning barriers (PJJ) include; (1) the policy of each school, (2) assignment of work directly (3) provision of study motivation and school visit, (4) grant of study quota from the government, (5) direct collection of duties, (6) increasing the professional ability of teachers in the use of technology and communication.
\end{abstract}

(C) 2021 Universitas Negeri Semarang

\begin{tabular}{lc}
\hline Alamat korespondensi: & E-ISSN 2685-4929 \\
Gedung C1, Lantai 1, FIS UNNES & \\
Kampus Sekaran, Gunungpati, Semarang, 50229 & \\
Email: feranigeographer@mail.unnes.ac.id & \\
\hline
\end{tabular}




\section{PENDAHULUAN}

Pendemi covid-19 memberi efek yang besar didalam segala bidang kehidupan, termasuk dalam bidang pendidikan, perubahan dalam dunia pendidikan ini terjadi cukup signifikan karena adanya kebijakan lockdown dan Pembatasan Sosial Bersekala Besar (PSBB). Pembatasan Sosial Bersekala Besar (PSBB) yang diatur dalam Peraturan Menteri Kesehatan Nomer 9 Tahun 2020. Yang kemudian diarahkan oleh pemerintah menuntut lembaga pendidikan untuk dengan cepat mengubah sistem belajarnya menjadi pembelajaran jarak jauh (PJJ) sistem pembelajaran online (daring) selama masa pandemi ini.

Sesuai dengan anjuran pemerintah yang dikeluarkan oleh Kementrian Pendidikan dan Kebudayaan (Kemendikbud) terkait kedaruratan Covid-19 ini tertuang dalam Surat Edaran Nomer 2 Tahun 2020 tentang Penecegahan dan Penanganannya di lingkungan Kemendikbud serta Surat Edaran Nomer 3 Tahun 2020 tentang Pencegahan Covid-19 pada Satuan Pendidikan. "Pemerintah mendorong para guru untuk tidak menyelesaikan semua materi dalam kurikulum. Yang paling penting adalah siswa masih terlibat dalam pembelajaran yang relevan seperti ketrampilan hidup, kesehatan dan empati." Diikuti dengan surat edaran pemerintah selanjutnya yakni Surat edaran Nomer 4 Tahun 2020 tentang Pelaksanaan Kebijakan Pendidikan dalam masa darurat penyebaran Coronavirus Disease (Covid-19) proses belajar mengajar yang dilakukan dari rumah dilaksanakan dengan ketentuan sebagai berikut: a) Belajar dari rumah melalui pembelajaran daring/jarak jauh dilaksanakan untuk memberikan pengalaman belajar yang bermakna bagi siswa, tanpa terbebani tuntutan menuntaskan seluruh capaian kurikulum untuk kenaikan kelas maupun kelulusan; b) belajar dari rumah dapat difokuskan pada pendidikan kecakapan hidup antara lain mengenai pandemi covid-19; c) aktivitas dan tugas pembelajaran belajar dari rumah dapat bervariasi antarsiswa, sesuai minat dan kondisi masing-masing, termasuk mempertimbangkan kesenjangan akses/fasilitas belajar di rumah; d) bukti atau produk aktivitas belajar dari rumah diberi umpan balik yang bersifat kualitatif dan berguna dari guru, tanpa diharuskan membri skor/nilai kuantitaitf.

Pembelajaran jarak jauh (PJJ) pada dasarnya pendidikan jarak jauh adalah jenis pendidikan dimana peserta didik berjarak jauh dari pendidik, sehingga pendidikan tidak dapat dilakukan secara tatap muka dan penyampaian pesan dari pendidik kepada peserta didik harus dilakukan melalui media (Setijadi, 2005: 1). Sedangkan menurut (Munir, 2012: 16) pembelajaran jarak jauh adalah ketika proses pembelajaran tidak terjadi kontak dalam bentuk tatap muka langsung antara pengajar dengan pembelajar. Hasibuan, Simarmata, dan (Sudirman, 2019) definisi pembelajaran Daring adalah metode belajar yang menggunakan model interaktif berbasis Internet dan Learning Manajemen System (LMS). Seperti menggunakan Zoom, Geogle Meet, Geogle Drive, dan sebagainya. Kegiatan daring diantaranya Webinar, kelas online, seluruh kegiatan dilakukan menggunakan jaringan internet dan komputer (Sofyan \&Abdul, 2019: 82)

Dapat disimpulkan bahwa pembelajaran jarak jauh (PJJ) merupakan bahwa pembelajaran jarak jauh adalah proses pembelajaran dimana adanya keterpisahan antara pendidik dan peserta didik yang dilakukan ditempat lain atau diluar tempat mengajar menggunakan suatu media yang menungkinkan terjadinya interaksi. Dengan diberlakukanya PJJ seharusnya bisa menjadi pembelajaran yang fleksibel bagi pendidik dan peserta didik. Namun pada kenyataannya justru ditemukan beberapa kendala atau hambatan dalam pembelajaran jarak jauh, baik hambatan yang muncul dari peserta didik ataupun hambatan dari pendidik.

Berbicara mengenai hambatan pembelajaran yang dihadapi pendidik dalam hal ini guru IPS di Kecamatan Gebog Kabupaten Kudus. 3) (Sapriya, 2009: 7) berpendapat bahwa IPS merupakan sebuah nama mata pelajaran integrasi dari mata pelajaran, sejarah, geografi dan ekonomi serta mata pelajaran sosial lainnya. (Sapriya, 2009: 12) Mata pelajaran Ilmu Pengetahuan Sosial (IPS) di SMP dan MTs merupakan salah satu mata 
pelajaran yang wajib ditempuh oleh siswa SMP dan MTs

Ada beberapa hambatan yang muncul dalam pembelajaran jarak jauh mulai dari perencanaan pembelajaran, pelaksanaan pembelajaran dan evaluasi pembelajaran.

Menurut Oemar Hamalik, hal-hal yang harus diperhatikan dalam membuat rencana pembelajaran yaitu: (a) Rencana yang dibuat harus disesuaikan dengan tersedianya sumber sumber. (b) Organisasi pembelajaran harus senantiasa memperhatikan situasi dan kondisi masyarakat sekolah, (c) Guru selaku pengelola pembelajaran harus melaksanakan tugas dan fungsinya dengan penuh tanggung jawab (Hamalik, 2009: 50).

Pelaksanaan pembelajaran adalah proses yang diatur sedemikian rupa menurut langkahlangkah tertentu agar pelaksanaan mencapai hasil yang diharapkan (Nana Sudjana, 2010: 136). UU No 20 Tahun 2003 tentang sistem pendidikan nasional berpendapat bahwa evaluasi adalah kegiatan pengendalian, penjaminan dan penetapan mutu pendidik terhadap berbagai komponen pendidikan pada setiap jalur, jenjang dan jenis pendidikan sebagai bentuk pertanggungjawaban peyelenggaraan pendidikan. Menurut (Anderson, 2003) terdapat tiga prinsip dalam penilaian pembelajaran, yaitu bermakna, transparansi dan adil.

Berdasarkan hasil observasi awal di lapangan dapat diperoleh keterangan dari guru IPS yang berperan penting dalam pembelajaran. Hasil observasi menunjukan bahwa pembelajaran selama pandemi covid-19 yang dilakukan dengan sistem pembelajaran jarak jauh (PJJ) sesuai dengan surat edaran yang telah dikeluarkan oleh pemerintah, selanjutnya dengan diberlakukannya PJJ muncul hambatan dalam pembelajaran terkait dengan perencanaan, pelaksanaan dan evaluasi pembelajaran. Kurangnya kesiapan guru menghadapi PJJ dan guru belum sepenuhnya memanfaatkan teknologi dan komunikasi yang berkaitan dengan pembelajaran sistem daring. Berdasarkan latar belakang tersebut, peneliti berfokus mengetahui: (1) bagaimanakah pembelajaran IPS jarak jauh dampak pandemi covid-19 di SMP/MTs Kecamatan Gebog
Kabupaten Kudus, (2) apa hambatan yang dihadapi guru IPS dalam pelaksanaan pembelajaran jarak jauh dampak pandemi covid-19 di SMP/MTs Kecamatan Gebog Kabupaten Kudus, (3) bagaimanakah upaya guru IPS dalam mengatasi hambatan pembelajaran jarak jauh dampak pandemi covid-19 di SMP/MTs Kecamatan Gebog Kabupaten Kudus?

\section{METODE}

Penelitian ini merupakan penelitian kualitatif, yaitu penelitian yang didasarkan kepada filsafat positivisme, digunakan untuk meneliti objek alamiah, teknik pengumpulan data yang dilakukan secara triangulasi, analisis data bersifat induktif dan hasil penelitian lebih menekankan kepada makna daripada generalisasi (Sugiyono, 2013: 1). Lokasi penelitian dilakukan pada 3 SMP/MTs di Kecamatan Gebog yaitu SMP 3 Satu Atap Gebog, SMP Bhakti Praja Gebog, dan MTs Hasyim Asyari 02 Gebog.

Fokus penelitian ini yaitu pembelajaran IPS jarak jauh dampak pandemi covid-19, hambatan yang dihadapi guru IPS dalam pelaksanaan pembelajaran jarak jauh serta upaya guru IPS dalam mengatasi hambatan pembelajaran jarak jauh dampak pandemi covid-19. Sumber data dalam penelitian ini dibedakan menjadi 2 yaitu sumber data primer dan sumber data sekunder (Sugiyono, 2017: 308). Data primer dalam penelitian ini diperoleh dengan melakukan observasi dan wawancara pada guru IPS, kepala sekolah dan beberapa informan peserta didik SMP/MTs di Kecamatan Gebog Kabupaten Kudus. Sedangkan data sekunder meliputi perangkat pembelajaran, arsip sekolah, foto dan dokumentasi. (Moleong, 2011: 330) menjelaskan bahwa keabsahan data pada penelitian kualitatif dapat diperoleh melalui triangulasi Teknik pengumpulan data dilakukan dengan teknik triangulasi. Pada penelitian ini menggunakan teknik triangulasi sumber. Selain itu teknik pengumpulan data dilakukan dengan observasi, wawancara dan dokumentasi. Teknik analisis data yang dalam penelitian meliputi 
pengumpulan data, reduksi data, penyajian data dan penarikan kesimpulan.

\section{HASIL DAN PEMBAHASAN}

Penelitian Kabupaten Kudus merupakan salah satu Kabupaten di Provinsi Jawa Tengah. Kabupaten Kudus memiliki 9 Kecamatan yaitu Kecamatan Kota, Kecamatan Bae, Kecamatan Jekulo, Kecamatan Dawe, Kecamatan Gebog, Kecamatan Kaliwungu, Kecamatan Jati, Kecamatan Mejobo, Kecamatan Undaan. Lokasi penelitian berada pada salah satu kecamatan yaitu Kecamatan Gebog Kabupaten Kudus tepatnya berada pada tiga SMP/MTs yaitu SMP 3 Satu Atap terletak di Jambu, Rahtawu, Gebog, Kab. Kudus, Jawa Tengah 59354, SMP Bhakti Praja terletak di Jl. Raya PR Sukun, Area Sawah, Jurang, Kec. Gebog Kab. Kudus, Jawa Tengah dan MTs Hasyim Asyari 02 Gebog terletak di Jl. Sudimoro, Karangmalang, Kec. Gebog Kab. Kudus, Jawa Tengah.

Pembelajaran IPS jarak jauh dampak pandemi covid-19 di SMP/MTs Kecamatan Gebog Kabupaten Kudus.

\section{a. Perencanaan pembelajaran IPS jarak jauh.}

Guru dianggap menguasai bahan ajar atau materi apabila telah melakukan persiapanpersiapan sebelum proses pembelajaran. Salah satunya indikator guru dikatakan menguasai materi jika ia telah mampu dalam pembuatan Rencana Pelaksanaan Pembelajaran (RPP) dan perangkat pembelajaran lainnya. Rencana Pelaksanaan Pembelajaran (RPP) yang kemudian dijadikan sebagai pegangaan guru dalam mengajar. Dimana isi dari RPP tersebut mencakup materi ajar, tujuan pembelajaran, langkah-langkah dalam mengajar, penilaian serta evaluasi.

Sistem pembelajaran yang sekarang dimana pembelajaran dilakukan dengan Pembelajaran Jarak Jauh (PJJ) maka Rencana Pelaksanaan Pembelajaran (RPP) yang digunakan juga menyesuaikan dengan kegiatan dan pola pembelajaran yang ada sekarang dimana pembelajaran yang didak bisa dilaksanakan secara langsung dan tatap muka antara guru dan peserta didik.

Hasil penelitian yang sudah dilakukan di tiga sekolah SMP 3 Satu Atap Gebog, SMP Bhakti Praja Gebog dan MTs Hasyim Asyari 02 beberapa guru IPS menjelaskan terkiat perencanaan pembelajaran jarak jauh dampak pandemi covid-19, adanya perubahan pembelajaran dari yang semula tatap muka ke pembelajaran jarak jauh (PJJ) ini menimbulkan beberapa perubahan termasuk dalam perencanaan pembelajaran di SMP/MTs Kecamatan Gebog yang sekarang menerapkan rpp daring dalam pembelajaran beberapa guru sudah menerapkan rpp daring. Namun ada juga guru yang berproses dalam menerapkan rpp daring, karena peralihan dari pembelajaran yang semula tatap muka harus berganti ke pembelajaran jarak jauh yang semua serba menggunakan media online.

\section{b. Pelaksanaan pembelajaran IPS Jarak Jauh.}

Selain perencanaan dalam pembelajaran jarak jauh, pelaksanaan pembelajaran jarak jauh (PJJ) juga merupakan suatu kegiatan yang bernilai edukatif, karena adanya interaksi yang terjadi antara guru sebagai pendidik dan peserta didik. Interaksi yang baik antara guru dan siswa dalam proses pelaksanaan pembelajaran agar dapat tercapainya hasil dan tujuan pembelajaran yang diharapkan.

Hasil peneltian dari masing-masing Kepala Sekolah SMP 3 Satu Atap, SMP Bhakti Praja, MTs Hasyim Asyari 02 bahwa di setiap sekolah mempunyai kebijakan dan himbauan kepada peserta didik dan guru terkait dengan pelaksanaan pembelajaran di masa pandemi covid-19, dari ketiga sekolah tersebut, kepala sekolah menerapkan kebijakan dalam pengumpulan tugas dilakukan peserta didik secara langsung kepada guru mata pelajaran masing-masing. Pengumpulan tugas dilakukan secara bergantian sesuai dengan jadwal yang telah ditentukan dimasing-masing sekolah dan dimasing-masing kelas untuk menghindari adanya perkumpulan dan disesuaikan dengan protokol kesehatan.

Pembelajaran selama pandemi ini dilaksanakan secara jarak jauh, 
pembelajarannya secara daring melalui grup di Whatsapp, menggunakan aplakasi Whatsapp pemberian tugas dan pengumpulan tugas tapi untuk yang tahun ajaran baru ini pengumpulan tugasnya dikumpulkan langsung diselokah dua minggu sekali. Tetapi untuk semester lalu semua dilaksanakan full memakai whatsapp, siswa juga disuruh belajar mandiri seperti membaca buku halaman sekian sampai halaman sekian kemudian merangkum, serta memberi reverensi link youtube untuk ditonton siswa terkait pembelajaran diselingi juga dengan pembelajaran dari TVRI. Pembelajaranya Jarak Jauh (PJJ) dengan sistem daring media yang saya pakai ada whatsapp, youtube, karena sebagaian anak tidak mempunyai gedget kalau saya mau pakai zoom, classrom akan kesusahan karena tidak ada sarana prasarana yang mendukung.

Berdasarkan hasil penelitian dengan guru IPS di tiga SMP 3 Satu Atap, SMP Bhakti Praja, MTs Hasyim Asyari 02 hampir semua guru menggunakan media pembelajaran whatsapp dalam proses pembelajaran karena media pembelajaran hampir semua peserta didik dan pendidik mempunyai media whatsapp sebagai alat komunikasi. Selain itu beberapa guru juga menggunakan media online yang lain untuk pembelajaran seperti youtube, vidio pembelajarn yang dibuat sendiri oleh guru, dan juga google clasroom.

\section{c. Evaluasi pembelajaran IPS Jarak Jauh.}

Evaluasi pembelajaran terkait dengan penilaian dengan siswa dilakukan dengan pemberian tugas-tugas bedanya ini pemberian tugas dan pengumpulan tugas pakainya online. Pengumpulan tugas kalau saya di Whatsapp personal chat, tapi sekarang tahun ajaran baru pengumpulan tugas ya whatsapp dan dikumpulkan langsung ketika siswa masuk sebagai bukti sudah mengerjakan.

Hambatan yang dihadapi guru IPS dalam pelaksanaan pembelajaran jarak jauh dampak pandemi covid-19 di SMP/MTs Kecamatan Gebog Kabupaten Kudus

\section{a. Hambatan guru IPS dalam perencanaan pembelajaran IPS Jarak Jauh}

Kemampuan dalam merencanakan pembelajaran bagi seorang guru sangat penting, karena guru sebagai pendidik harus mempunyai tujuan dalam pembelajaran. Oleh sebab itu guru harus memahami arti, tujuan RPP dan menguasai isi didalamnya, kemampuan dalam merencanakan rencana pembelajaran. Perencanaan pembelajaran merupakan suatu prediksi pendidik terhadap apa yang akan dilakukan peserta didik dalam proses kegiatan pembelajaran. Yang berisi tujuan dari pembelajaran, isi materi pembelajaran, bagaimana metode dan teknik pembelajaran peserta didik dan mengetahui bagaimana siswa telah mencapainya dengan penilaian pembelajaran.

Perancangan RPP memiliki tujuan sebagai pedoman bagi guru untuk melakukan praktik atau tindakan mengajar di kelas. Oleh karena itu, apa yang dilakukan guru dalam proses pembelajaran harus berasal dari persiapan yang telah disusun seblumnya agar tujuan dapat tercapai. Dalam pembelajaran jarak juah dampak pandemi covid-19 tentu sama memerlukan perencanaan pembelajaran yang matang, tetapi peralihan pembelajaran dari tatap muka ke pembelajaran jarak jauh mengalami perbedaan termasuk dalam perencanaan pembelajaran. Dari perubahan yang ada menimbulkan beberapa kendala dalam pembelajaran dari guru maupun peserta didik.

Berdasarkan hasil penelitian di salah satu sekolah di Kecamatan Gebog,yakni SMP 3 Satu Atap Gebog yang telah dilakukan dalam hal perencanaan pembelajaran memiliki kesulitan dalam koneksi internet yang ada, karena sekolah ini berada pada lereng gunung muria sehingga menyebabkan koneksi internet yang tidak stabil. hal ini menjadikan terganggunya proses pembelajaran jarak jauh. Selanjutnya hambatan di tiga sekolah dalam perencanaan pembelajaran yang dihadapi guru adalah kurangnya kesiapan guru menghadapi pembelajaran jarak jauh(PJJ), dari yang semula pembelajaran tatap muka dengan perencanaan program pembelajaran tatap muka, harus beralih ke PJJ dengan media online sedangkan kemampuan guru yang tidak semua guru mahir mengoprasikan teknologi dan komunikasi. Dari semua guru mengeluhkan hal yang sama karena 
kurangnya kesiapan menghadapi PJJ, serta keterbatasan kemampuan guru dalam penggunaan media teknologi dan komunikasi yang belum diiringi dengan sosialisasi dari pemerintah mengenai pembelajaran jarak jauh serta keterbatasan koneksi internet yang ada.

\section{b. Hambatan guru IPS dalam pelaksanaan pembelajaran IPS Jarak Jauh}

Hambatan guru IPS dalam pelaksanaan pembelajaran jarak jauh yakni Berdasarkan hasil wawancara di tiga sekolah diketahui hambatan ketiga sekolah pembelajaran jarak jauh yang menggunakan media online dan sarana prasarana pembelajaran yang mendukung pembelajaran. Tetapi pada kenyataannya tidak semua peserta didik mempunyai sarana prasarana pembelajaran seperti gedget, disisi lain PJJ yang mengunakan media pembelajaran online, dari ketiga sekolah media pembelajaran yang digunakan guru yaitu whatsapp, youtube, vidio pembelajaran. Dari ketiga sekolah media pembelajaran yang paling sering digunakan yaitu whatsapp, keterbatasan kemampuan beberapa guru dalam pengoprasian teknologi informasi dan komunikasi termasuk media pembelajaran berbasis online menjadikan kurangnya pemahaman peserta didik. Serta kurangnya komunikasi dalam pembelajaran jarak jauh antara guru dan peserta didik dan dengan sarana pembelajaran yang kurang peserta didik cenderung pasif dalam pembelajaran.

\section{c. Hambatan guru IPS dalam evaluasi pembelajaran IPS Jarak Jauh.}

Evaluasi didapatkan memalui penugasanpenugasan yang diberikan kepada siswa. Menurut Anderson (2003) terdapat tiga prinsip dalam penilaian pembelajaran, yaitu bermakna, transparansi dan adil. Ketika pembelajaran jarak jauh ketiga prinsip tersebut tidak bisa dipenuhi oleh guru secara maksimal. Evaluasi dari tugastugas yang diberikan kemudian tugas dikerjakan dan dikumpulkan melalui whatsapp ke guru mata pelajaran, karena tidak bertatap muka langsung dengan anak jadi transparansi apakah dikerjakan langsung atau tidak kita tidak tau, apakah hasil pekerjaan sendiri atau dibantu kakaknya atau orangtuanya.
Upaya guru IPS dalam mengatasi hambatan pembelajaran jarak jauh dampak pandemi covid-19 di SMP/MTS Kecamatan Gebog.

\section{a. Upaya dalam mengatasi hambatan perencanaan pembelajaran jarak jauh dampak pandemi covid-19.}

Berikut ini adalah upaya guru IPS dalam mengatasi hambatan pembelajaran jarak jauh di SMP 3 Satu Atap, SMP Bhakti Praja Gebog, MTS Hasyim Asyari 02 Gebog. Selanjutnya untuk upaya yang dilakukan tiap-tiap guru mapel IPS di masing masing sekolah dalam mengatasi hambatan yang muncul dalam perencanaan pembelajaran jarak jauh.

Terkait perencanaan pembelajaran upaya yang sudah dilakukan dengan mengikuti anjuran dari pemerintah menggnakan rpp daring, dengan eksplor mempelajari media pembelajaran tidak hanya whatsapp sebagai media pembelajaran. Mengikuti pelatihan yang diselenggarakan melalui zoom meeting, selain menambah pengetahuan mengenai PJJ baik yang diselenggarakan dinas pendidikan maupun dilaur dinas pendidikan, beliau juga menuturkan dengan menggunakan zoom agar berlatih dalam penggunaan teknologi untuk disalurkan ke siswa.

Berdasarkan hasil penelitian yang telah dilakukan upaya yang dilakukan guru IPS di tiga sekolah di Kecamatan Gebog Kabupaten Kudus yitu SMP 3 Satu Atap, SMP Bhakti Praja dan MTS Hasyim Asyari 02 cara yang dilakukan untuk mengatasi hambatan yang muncul dalam perencanaan pembelajaran yang muncul dengan adanya perubahan rpp yang sebulmya ke rrp daring, guru sudah mengikuti dan berporses anjuran dari pemerintah. Upaya yang lain dilakukan dengan mengikuti pelatihan-pelatihan memalui zoom meeting namun untuk hal ini belum semua guru mengikuti pelatihan, namun belum semua guru IPS mengikuti pelatihan.

\section{b. Upaya dalam mengatasi hambatan pelaksanaan pembelajaran jarak jauh dampak pandemi covid-19. \\ Pembelajaran jarak jauh (PJJ) dampak} pandemi covid-19 yang memunculkan hambatan dan juga tantangan dalam 
pembelajaran, dalam hal ini ada beberapa upaya yang dilakukan guru IPS dalam mengatasi hambatan yang ada. Upaya yang dilakukan guru IPS mengatasi hambatan pelaksanaan pembelajaran di SMP/MTs Kecamatan Gebog berdasarkan hasil wawancara yang telah dilakukan dapat disimpulkan bahwa upaya yang telah dilakukan guru dalam mengatasi hambatan pelaksanaan pembelajaran yaitu:

(1) Untuk mengatasi kendala tidak semua peserta didik mempunyai sarana prasarana pembelajaran jarak jauh yang mendukung maka dari ketiga sekolah yang diteliti menerapkan pemberian dan pengumpulan tugas dilakukan langsung di sekolah sesuai dengan jadwal yang telah ditentukan tiap sekolah. Hal ini juga dilakukan untuk mengatasi kendala dimana tidak semua sekolah di Kecamatan Gebog memeiliki koneksi internet yang mendukung.

(2) Upaya meningkatkan keaktifan siswa dalam PJJ maka guru selalu memberikan motivasi kepada peserta didik, upaya yang lain dilakukan guru IPS dengan home visit hal ini dilakukan oleh guru di MTs Hasyim Asyari 02 dengan pemberian motivasi kepada peserta didik dalam mengikuti pembelajaran, upaya yang lain dilakukan kepada peserta didik yang tidak memiliki gedget/smartphone dengan saling bertukar informasi antar teman agar tidak tertinggal dalam pembelajaran

(3) Untuk mengatasi penggunaan kuota internet belajar yang besar, hal ini sudah diantisipasi oleh kemdikbud dengan pemberian kuota belajar gratis

(4) Untuk mengembangkan keprofesionalan secara berkelanjutan dengan mengikuti seminar dan peningkatan penggunaan teknologi informasi dan komunikasi agar pembelajaran yang digunakan guru tidak monoton.

\section{c. Upaya dalam mengatasi hambatan evaluasi pembelajaran jarak jauh dampak pandemi covid-19.}

Sama halnya dengan perencanaan dan pelaksanaan pembelajaran jarak jauh yang terdapat beberapa hambatan, evaluasi dalam pembelajaran jarak jauh juga mengalami hambatan seperti pada penjelasan masing-msing guru IPS di tiap sekolah. Berdasarkan hasil wawancara di tiga sekolah dengan adanya hambatan pembelajaran jarak jauh (PJJ) maka harus adanya upaya guru IPS dalam mengatasi hambatan evaluasi pembelajaran tersebut. Upaya yaitu usaha, akal atau ikhtiar untuk mencapai suatu maksud, dengan memecahkan masalah dan mencari jalan keluar untuk mencapai suatu tujuan. Upaya yang dilakukan di tiga sekolah yakni SMP 3 Satu Atap Gebog, SMP Bhakti Praja Gebog, dan MTs Hasyim Asyari 02 mengatsi hambatan yang muncul dari masing masing sekolah dengan pengumpulan tugas-tugas yang dilakukan secara langsung dua minggu sekali, sesuai dengan jadwal yang telah dtetapkan tiap sekolah dan dengan tetap mematuhi perotokol kesehatan.

\section{PEMBAHASAN}

Dalam Pembelajaran IPS jarak jauh dampak pandemi covid-19 di SMP/MTs Kecamatan Gebog Kabupaten Kudus.

\section{a. Perencanaan pembelajaran IPS jarak jauh dampak pandemi covid-19 di SMP/MTs Kecamatan Gebog Kabupaten Kudus.}

Dalam Pembelajaran Jarak Jauh (PJJ) tentu saja berbeda dengan pembelajaran normal sebelumnya ketika pembelajaran antara guru dan peserta didik. Proses pembelajaran menuntut sebuah perencanaan, perencanaan pembelajaran menjadi salah satu hal yang sangat penting dilakukan oleh guru sebagai pendidik agar mampu memaksimalkan seluruh komponen pembelajaran. Perencanaan pembelajaran merupakan tahap awal dalam pembelajaran. Pada tahap perencanaan pembelajaran guru membuat perangkat pembelajaran yang berupa program tahunan, program semster, silabus dan juga Rencana Pelaksanaan Pembelajaran (RPP).

Dalam hasil penelitian yang dilakukan peneliti di SMP 3 Satu Atap, SMP Bhakti Praja, MTs Hasyim Asyari 02 Kecamatan Gebog Kudus dapat dikatakan bahwa sebelum melakukan kegiatan pembelajaran guru sudah menyiapkan Rencana Pelaksanaan Pembelajaran (RPP) beberapa guru mata pelajaran IPS menjelaskan terkait perencanaan 
pembelajaran jarak jauh dampak pandemi covid-19, dengan adanya perubahan pembelajaran dari yang semua dilaksanakan dengan tatap muka dan sekarang beralih (PJJ) menimbulkan adanya beberapa perubahan yakni dalam penggunaan RPP daring di tahun ajaran 2020/2021. Dalam hal ini beberapa guru sudah menerapkan rpp daring sesuai dengan anjuran dari pemerintah ada juga yang masih berproses dalam penerapan rpp daring. Perencanaan pembelajaran tersebut didalamnya terkait dengan cara, metode, maupun media dalam pelaksanaan pembelajaran. Penelitian yang dilakukan menunjukkan bahwa guru IPS pada tiga SMP di Kecamatan Gebog guru melakukan perencanaan pembelajaran yang sesuai dengan tujuan pembelajaran yang ingin dicapai perbedaanya secara semua dilakukan dengan berbasir online.

b. Pelaksanaan pembelajaran IPS jarak jauh dampak pandemi covid-19 di SMP/MTs Kecamatan Gebog Kabupaten Kudus.

Diberlakukanya pembelajaran Jarak Jauh

(PJJ) tentunnya menimbulkan tantangan baru bagi guru dalam melaksanakan proses pembelajaran yang semula dilaksanakan kegiatan belajar mengajar di didalam kelas tetapi dengan kebijakan baru yang dikeluarkan oleh pemerintah pembelajaran di laksanakan dengan jarak jauh antara guru dan peserta didik. Pelaksanaan pembelajaran jarak jauh dilakukan dengan langkah-langkah yang telah disiapkan dalam rencana pelaksanaan pembelajaran (RPP) bedanya dahulu dilakukan secara langsung untuk PJJ pembelajaran dilakukan dengan sistem daring.

Hal ini sesuai dengan pendapat Nana (Sudjana, 2010:136) Pelaksanaan pembelajaran adalah proses yang diatur sedemikian rupa menurut langkah-langkah tertentu agar pelaksanaan mencapai hasil yang diharapkan. Selanjutnya terkait dengan pelaksanaan pembelajaran di masa pandemi covid-19 di tiga sekolah yang diteliti di Kecamatan Gebog yaitu SMP 3 Satu Atap, SMP Bhakti Praja, MTs Hasyim Asyari 02. Pembelajaran ditiga sekolah ini dilaksankan dengan online (daring) menggunakan aplikasi Whatsapp, Youtube, vidio pembelajaran ataupun media pembelajaran yang mendukung lainnya dalam pembelajaran jarak jauh. Dalam pembelajaran jarak jauh aplikasi whatsapp adalah aplikasi yang paling sering digunakan guru untuk menyampaikan materi, pemberian tugas, dan pengumpulan tugas. Keegan yang dijelaskan (Warsito, 2007) menyatakan bahwa, ada beberapa karakteristik pendidikan jarak jauh antara lain: (1) Adanya keterpisahan pembelajaran yang mendekati unsur permanen antara tenaga pengajar dari perserta didik selama program pendidikan berlangsung, (2) Adanya keterpisahan antara seseorang perserta didik dengan perserta didik lainnya selama program pendidikan. (3) Adanya suatu institusi yang mengelolah program pendidikannya, (4) Pemanfaatan sarana komunikasi yang baik mekanis sebagai bahan belajar. (6) Penyedian sarana komunikasi dua arah sehingga perserta didik dapat mengambil inisiatif dialog dan mencari dan mengolah manfaatnya

c. Evaluasi pembelajaran IPS jarak jauh dampak pandemi covid-19 di SMP/MTs Kecamatan Gebog Kudus.

Dalam pembelajaran, evaluasi pembelajaran sangat diperlukan oleh seorang guru dalam kegiatan belajar mengajar dan tentunya dilaksanakan dengan sistematis dan terencana dengan baik sehingga mampu menghasilkan suatu pembelajaran yang maksimal sehingga dapat mencapai tujuan pembelajaran yang hendak dicapai. Walaupun sudah ada anjuran dari Kemendikbud tentang RPP yang sesuai dengan pembelajaran jarak jauh di masa pandemi covid-19 tetapi belum adanya sosialisasi dari pemerintah dan lembaga terkiat mengenai pembelajaran di masa pandemi covid-19 di Kecamatan Gebog.

Hambatan yang dihadapi guru IPS dalam pelaksanaan pembelajaran jarak jauh dampak pandemi covid-19 di SMP/MTs Kecamatan Gebog Kudus.

a. Hambatan guru IPS dalam perencanaan pembelajaran jarak jauh dampak pandemi covid-19 di SMP/MTs Kecamatan Gebog Kabupaten Kudus. 
Temuan di lapangan terdapat beberapa hambatan yangmana dalam kegiatan pembelajaran yang semula dilakukan dengan tatap kemudian dengan adanya wabah pandemi covid-19 pemerintah mengeluarkan kebijakan lockdown dan Pembatasan Sosial Bersekala Besar (PSBB) yang kemudian berdampak pada kegiatan pembelajaran yang dilakukan dengan Pembelajaran Jarak Jauh (PJJ) hal ini menjadikan kurangnya kesiapan guru dalam menghadapi PJJ. Selanjutnya dengan perubahan rencana pelaksanaan pembelajaran menggunakan RPP daring. Dengan pembelajaran jarak jauh tentu ada perbedaan dengan pembelajaran tatap muka, yangmana sekarang pembelajaran menggunakan media online tetapi tidak semua daerah mendapatkan koneksi internet yang baik.

Seperti yang terjadi di salah satu sekolah di Kecamatan Gebog yaitu SMP 3 Satu Atap dengan letak geografis yang lebih tinggi dari derah sekitar karena berada di daerah pegunungan sehingga menyebabkan koneksi internet kurang baik dan tidak stabil. Hal ini memunculkan hambatan sebagai guru dalam proses pembelajaran. Selain itu sosialisai dari pemerintah terkait pembelajaran jarak jauh dirasa belum maksimal karena belum semua guru IPS mengikuti pelatihan tersebut.

\section{b. Hambatan guru IPS dalam pelaksanaan pembelajaran jarak jauh dampak pandemi covid-19 di SMP/MTs Kecamatan Gebog Kabupaten Kudus.}

Dalam hal pelaksanaan pembelajaran dari wawancara yang sudah dilakukan dengan informan didapatkan bahwa hambatanhambatan pelaksanaan yang dihadapi dalam Pembelajaran Jarak Jauh (PJJ) di tiga sekolah di Kecamatan Gebog yaitu : (1) Segi letak geografis sekolah disini juga mempengaruhi dalam Pembelajaran Jarak Jauh (PJJ) yakni mempengaruhi koneksi internet yang ada, dengan diberlakukannya pembelajaran jarak jauh maka pembelajaran menggunakan pembelajaran daring yang membutuhkan koneksi internet, tetapi tidak semua tempat atau lokasi mendukung, koneksi internet yang diakses guru maupun peserta didik, sehingga mengakibatkan kesulitan dalam kegiatan pembelajaran. Jaringan internet, merupakan hal sangat penting dalam pembelajaran jarak jauh dengan sistem daring. Namun pada kenyataanya di lapangan banyak masyarakat yang mengeluhkan mengenai jaringan atau koneksi internet yang minim. Seperti yang terjadi di SMP 3 Satu Atap Gebog minimnya jaringan internet menjadikan pembelajaran jarak jauh mengalami hambatan. (2) Kendala dimana tidak semua peserta didik mempunyai gadget atau smartphone, disetiap sekolah dijumpai bahwa tidak semua peserta didik memakai smartphone sebagian dari peserta didik masih memakai ponsel biasa yang tidak bisa digunakan dalam proses pembelajaran jarak jauh. Selain itu kendala yang berkaitan dengan penggunaan gadget yaitu sebagian dari peserta didik yang sudah memakai smartphone kapasitas penyimpanan yang tidak terlalu besar, sehingga ketika pembelajaran dan guru memakai media pembelajaran yang mengharuskan peserta didik mengunduh sebuah materi pembelajaran kendala yang dihadapi ruang penyimpanan dihandphone tidak mencukupi.

Dengan seperti itu guru harus memfoto kembali materi yang inti dan penting sehingga semua peserta didik bisa membuka dan mempelajari. Sehingga dengan diberlakukanya Pembelajaran Jarak Jauh (PJJ) dimasa pendemi covid-19 memberikan hambatan dalam pembelajaran dengan masih adanya peserta didik yang tidak mempunyai smartphone ataupun dalam penggunaan smartphone masih bergantung kepada orang tua sehingga kadang peserta didik tidak mengetahui informasi atau tugas-tugas yang diberikan secera langsung karena kendala dalam pengunaan handphone yang dalam penggunaannya masih bergantian, hal ini menjadikan kurangnya komunikasi anatar pendidik dan peserta didik dan juga ketika mengumpulkan tugas-tugas sering tidak tepat waktu atau malah lupa dengan pengugasan yang diberikan. (3) Peserta didik yang cenderung pasif dalam kegiatan pembelajaran dengan jarak jauh, karena dengan pembelajaran jarak jauh dimana anatara guru dan peserta didik tidak saling bertatap muka. Siswa cenderung hanya mengikuti materi-materi yang diberikan atau tugas-tugas yang diberikan guru tidak ada semangat untuk belajar sendiri 
atau mencari materi sendiri. (4) Dengan pembelajaran daring pembelajaran online maka guru maupun peserta didik harus menggunakan kuota data internet yang lebih banyak dari penggunaan biasanya. (5) Kemampuan profesional guru dalam pemanfaatan teknologi informasi dan komunikasi. Serta belum semua guru mampu menggunakan dan memanfatkan aplikasi belajar secara maksimal sehingga menjadikan pembelajaran monoton terbatas pada penugasan melalui whatsapp. Hal ini berkaitan dengan kemampuan profesional guru yang berkaitan dengan mengelola, mengorganisasi pembelajaran. Kemampuan pengorganisasian mempersyaratkan seorang guru agar dapat mengurutkan materi yang disampaikan secara logis sehingga keterkaitan antara topik satu dengan yang lain jelas.

Dari temuan diatas tentang hambatan pembelajaran jarak jauh di SMP/MTs Kecamatan Gebog yakni SMP 3 Satu Atap, SMP Bhakti Praja, MTs Hasyim Asyari 02 sesuai dengan pendapat menurut (Attri, 2012) Terdapat beberapa masalah atau kendala yang dihadapi pada pelaksanaan pembelajaran jarak jauh ini, seperti biaya, motivasi belajar, layanan, umpan balik, kurangnya pengalaman serta kebiasaan. Dan juga diperkuat dengan pendapat (Buselic, 2012) Kurangnya interaksi yang efektif, minimnya pengorganisasian merupakan salah satu yang menjadi kendala pembelajaran jarak jauh, pembelajaran jarak jauh yang efektif tentu harus didukung dengan konten yang diberikan, fasilitas koneksi internet serta perhatian dan ketersediaan yang cukup besar.

\section{c. Hambatan guru IPS dalam evaluasi pembelajaran jarak jauh dampak pandemi covid-19 di SMP/MTs Kecamatan Gebog Kabupaten Kudus.}

Evaluasi pembelajaran (Hamalik, 2010: 29) yang berpendapat bahwa evaluasi merupakan komponen kurikulum dengan evaluasi dapat diperoleh informasi yang akurat mengenai penyelenggaraan dan keberhasilan belajar siswa. Guru menggunakan evaluasi mengukur keberhasilan belajar siswa dalam menerima materi yang disampaikan dan sebagai pengambilan keputusan dalam penyelengaraan pembelajaran kedepannya mengingat menfaat evaluasi mempunyai banyak kegunaan bagi peserta didik maupun bagi guru itu sendiri.

Kendala yang digadapi dalam evaluasi pembelajaran jarak jauh di masa pandemi covid-19, pembelajaran dengan menggunakan sistem daring yangmana adanya keterpisahan antara guru dan peserta didik tidak saling bertatap muka dalam pembelajaran. hal ini tentu akan memunculkan hambatan termasuk dalam evaluasi pembelajaran diantara yaitu dalam pengumpulan tugas-tugas peserta didik yang tidak mengumpulkan tugas esuai dengan deadline yang telah ditentukan, sehingga guru harus bekerja dua kali untuk mengingatkan peserta didik mengenai tugas yang diberikan.

Bahkan ada juga siswa yang tidak mengumpulkan tugas hal ini diketahui ketika peneliti melakukan penelitian di beberapa sekolah di Kecamatan Gebog Kabupaten Kudus. Berdasarkan kurikulum 2013, penilaian kegiatan pembelajaran meliputi aspek afektif, kognitif dan psikomotor. Menurut (Anderson, 2003) terdapat tiga prinsip dalam penilaian pembelajaran, yaitu bermakna, transparansi dan adil. Dalam Pemelajaran Jarak Jauh (PJJ) ketiga prinsip tersebut tidak bisa dipenuhi secara maksimal oleh guru ketika pembelajaran jarak jauh. Transparansi dalam penilaian pembelajaran jarak jauh belum bisa dilakuakan maksimaloleh guru dikarenakan dalam kegiatan pembelajaran jarak jauh dimana adanya keterpisahan antara guru dan peserta didik, jadi dalam pemberian tuga guru tidak bisa mengetahui apakah si peserta didik mengerjakan sendiri atau dibantu orang lain atau malah meniru hasil tugas orang lain menyebabkan kurangnya transparansi dalam penyelesaian tugas yang berdampak dalam penilaian oleg guru.

Adil dalam penilaian mempunyai makna bahwa setiap peserta didik mempunyai kesempatan sama dalam sistem penilaian, bukan berarti nilai yang sama, tetapi nilai yang sesuai dengan kemampuan siswa. Fakta di lapangan menunjukan bahwa semua siswa memperoleh nilai maksimal ketika diberi soal. Ini menjadikan pertanyaan bagi guru, apakah peserta didik benar memahami materi yang diberikan atau malah mendapat bantuan dari orang dewasa atau malah mencontek ketika 
mengerjakan. Sehingga yang terjadi adalah guru tidak dapat menilai ketercapaian pembelajaran secara obyektif sesuai dengan kemampuan peserta didik.

Upaya guru IPS dalam mengatasi hambatan pembelajaran jarak jauh dampak pandemi covid-19 di SMP/MTs Kecamatan Gebog Kabupaten Kudus.

a. Upaya guru IPS dalam mengatasi hambatan pembelajaran jarak jauh dampak pandemi covid-19 di SMP/MTs Kecamatan Gebog Kabupaten Kudus.

Upaya dapat dikatakan sebagaisuatu usaha, akal, ikhtiar untuk mencapai suatu maksud, memecahkan persoalan dengan mencari jalan keluar. Guru atau pendidik adalah orang yang mengajar dan membari pengajaran karena hak dan kewajibannya bertanggung jawab kepada peserta didik (Ramayulis, 2002).

Upaya yang dilakukan guru IPS dengan perubahan rpp yang sebulmnya ke rrp daring, guru sudah mengikuti dan berporses anjuran dari pemerintah. Upaya yang lain dilakukan untuk mengatasi kurangnya kesiapan guru IPS mengahdapi pembelajaran jarak jauh dan upaya untuk mengembangkan keprofesionalan guru dalam penggunaan teknologi komunikasi dan informasi dengan mengikuti seminar dan pelatihan yang diadakan oleh dinas pendidikan maupun diluar dinas pendidikan agar guru memiliki wawasan yang semakin luar, melalui zoom meeting menganai pembelajaran daring namun dalam hal ini belum maksimal karena dari hasil wawancara yang didapatkan belum semua guru pernah mengikuti zoom meeting yang diselenggarakan pemerintah atau lembaga terkait.

b. Upaya guru IPS dalam mengatasi hambatan pembelajaran jarak jauh dampak pandemi covid-19 di SMP/MTs Kecamatan Gebog Kabupaten Kudus.

Berdasarkan kendala yang dihadapi dalam pelaksanaan pembelajaran IPS jarak jauh maka masing-masing guru memiliki solusi sendiri untuk mengtasi kendala atau hambatan yang dihadapi. Seperti hambatan guru terkait dengan perbedaan letak geografis sekolah yang menjadikan koneksi internet tidak stabil dan tidak semua peserta didik memiliki sarana prasarana pembelajaran upaya yang dilakukan dengan pemberian dan pengumpualan tugas dilakukan secara langsung sesuai dengan jadwal masing-masing kelas. Selain itu untuk peserta didik yang belum memiliki gedget solusi yang dilakukan guru dengan memberi tahun kepada murid yang sudah mempunyai gedget untuk memberitahu teman lainnya.

Kendala dalam hal siswa yang cendrung pasif dalam pembelajaran, atau bahkan tidak mengikuti pembelajaran yang diberikan guru upaya yang dilakukan dengan memberikan menanyai secara pribadi dan memberikan motivasi agar peserat didik semangat dalam belajar. Selain itu juga guru melakukan home visit terhadap peserta didik menanyakan kenapa tidak aktif dalam pembelajaran dan memberikan semangat agar giat dalam belajar. Selanjutnya terkait dengan pembelajaran jarak jauh yang menggunakan kuota belajar yang besar sekarang sudah ada upaya dari pemerintah melalui kemendikbud dengan pemberian kuota belajar kepada peserta didik dan juga pendidik.

Hambatan guru dalam pemanfaatan teknologi dan komunikasi yang kurang maksimal sudah dilakukan beberapa guru dengan pembelajaran yang tidak hanya dilakukan melalui whatsapp tetapi juga menggunakan video pembelajaran diselingi dengan pemberian berupa hiburan sehingga pembelajaran tidak monoton pemberian tugastugas, dengan memberikan pembelajaran dari video pembelajaran yang dibuat oleh pendidik sehingga dalam penyampaian materi lebih berasa hidup dengan adanya video pembelajaran dari guru mapel IPS ini atau juga dengan pemberian materi dari youtube berupa video pembelajaran yang disajikan dengan animasi yang dapat menarik perhatian peserta didik. Namun untuk hal ini belum semua guru menerapkan hal yang sama sebagian masih terfokus dalam penggunaan media whatsapp.

\section{c. Upaya guru IPS dalam mengatasi hambatan evaluasi pembelajaran jarak jauh dampak pandemi covid-19 di SMP/MTs Kecamatan Gebog} Kabupaten Kudus. 
Terdapat tiga prinsip dalam penilaian pembelajaran, yaitu bermakna, transparansi dan adil (Anderson, 2003). Dalam Pemelajaran Jarak Jauh (PJJ) ketiga prinsip tersebut tidak bisa dipenuhi secara maksimal oleh guru ketika pembelajaran jarak jauh.

Dengan hambatan tersebut berdasarkan hasil wawancara di tiga sekolah, SMP 3 Satu Atap, SMP Bhakti Praja dan MTs Hasyim Asyari 02 Kecamatan Gebog Kabupaten Kudus salah salau upaya yang bisa dilakukan saat ini menghadapi Pembelajaran Jarak Jauh dampak pandemi covid-19 dengan siswa masuk kesekolah dua minggu dua kali sesaui dengan jadwal sekolah masing-masing dengan tetap mematuhi protokaol kesehatan untuk pengumpulan tugas.

Hal ini dilakukan di tahun pelajaran 2020/2021 karena tiap sekolah belajar dari hambatan di semster sebelumnya terakit PJJ, untuk hal ini sudah didasarkan kesepakatan anatara pihak kesekolah dan orang tua wali. Dukungan dari pihak sekolah dan orangtua akan berpengaruh dalam mutu pendidikan di sekolah bahwasannya kemajuan yang didapatkan oleh peserta didik yang akan membawa perubahan bagi sekolah.

\section{SIMPULAN}

Pembelajaran yang dilakukan selama pandemi covid-19 di SMP 3 Satu Atap, SMP Bhakti Praja Gebog, MTS Hasyim Asyari 02 Kecamatan Gebog Kabupaten Kudus dalam hal perencanaan, pelaksanaan dan evaluasi dilaksanakan dengan pembelajaran jarak jauh (PJJ), menggunakan sistem pembelajaran online(daring) dengan menggunakan media pembelajaran seperti whatsapp, vidio pembelajaran dari guru, youtube.

Hambatan yang dihadapi guru IPS dalam pembelajaran jarak jauh yaitu dalam hal perencanaan, pelaksanaan dan evaluasi. Pertama letak geografis dari masing-masing sekolah yang berbeda walaupun dalam satu lingkup kecamatan, SMP 3 Satu Atap yang secara letak geografis terletak di daerah pegunungan yang lebih tinggi dari sekolah yang lain cenderung mengalami hambatan dalam hal koneksi internet yang minim dan kurang tidak stabil, sehingga guru kesulitan dalam memberikan materi pembelajaran dan memberikan penugasan.

Kedua tidak semua peserta didik mempunyai sarana prasarana pendukung pembelajaran jarak jauh yang memadahi seperti peserta didik yang belum mempunyai gadget/smartphone, gadget/smartphone peserta didik yang masih bergabung dengan orang tua atau kakak. Hal ini menjadikan kurangnya komunikasi antara peserta didik dan guru, peserta didik tidak bisa mengikuti pembelajaran tepat waktunya dan tertinggal dalam mengetahui informasi menganai penugasan dan materi pembelajaran, sehingga guru harus mengingatkan kembali mengulang tugas yang diberikan guru harus bekerja lebih ekstra dalam proses pembelajaran jarak jauh.

Ketiga, pembelajaran jarak jauh peserta didik cenderung pasif. Keempat pembelajaran jarak jauh memerlukan kuota internet yang lebih besar. Kelima kompetansi guru yaitu kemampuan profesional yakni penguasaan materi secara luas dan mendalam yang memungkinkan membimbing peserta didik memenuhi standar nasional pendidikan, yang juga terkait dalam penggunaan dan pemanfaatan aplikasi-aplikasi belajar secara maksimal belum semua guru menggunakan aplikasi belajar. Kebanyakan masih menggunakan media whatsapp untuk memberikan materi dan penugasan hal ini menjadikan pembelajaran kurang bervariasi dan monoton.

Dengan hambatan yang dipaparkan seperti diatas ada beberapa langkah solusi yang sudah laksanakan baik dari pemerintah maupun dari pihak sekolah, mulai dari siswa masuk kesekolah hanya untuk pengumpulan tugas yang dilakukan secara langsung dengan jadwal yang sudah dientukan, guru mengikuti seminar dan pelatihan terkait baik dalam dinas pendidikan maupun diluar dinas pendidikan, pemberian motivasi kepada peserta didik yang pasif dalam pembelajaran serta home visit yang dilakukan guru, sudah adanya bantuan kuota internet gratis dari Kemendikbud dan juga peningkatan kemampuan guru dalam pembelajaran dengan membuat video pembelajaran yang menarik. 


\section{DAFTAR PUSTAKA}

Anderson. 2003. Critical Thinking Accross the Disciplines. Makalah pada Faculty Development Seminar in New York City Colladge of Technology New York.

Attri, A. K. 2012. Distance Education: Problems And Solution International. Journal of Behavioral Social And Movement Sciences. 1(4), 42-58.

Buselic, M. 2012. Distance Learning-Concepts and contribution. Oeconomica Jadertina, I, 23-24.

Hamalik, Oemar. 2009. Proses Belajar Mengajar. Jakarta: PT Bumi Aksara.

2010. Proses Belajar Mengajar. Jakarta: PT Bumi Aksara.

Hasibuan, MS \& Simarmata, Janner \& Sudirman, Acai. (2019). ELearning: Implementasi, Strategi dan Inovasinya. Medan: Yayasan Kita Menulis.

Moleong. 2011. Metodologi Penelitian Kualitatif. Bandung: PT Remaja Rosdakarya.

Munir. 2012. Pembelajaran Jarak Jauh Berbasis Teknologi Informasi dan Komunikasi. Bandung: Alfabeta.
Peraturan Menteri Kesehatan Nomer 9 Tahun 2020.

Ramayulis. 2002. Ilmu Pendiidikan Islam. Jakarta: Kalam Mulia.

Sapriya. 2009. Pendidikan IPS Konsep Dan Pembelajaran. Bandung:PT Remaja Rosdakarya.

Setijadi. 2005. Buku pedoman pendidikan Jarak Jauh. Jakarta: Universitas terbuka.

Sofyana \& Abdul. 2019. Pembelajaran Daring Kombinasi Berbasis Whatsapp Pada Kelas Karyawan Prodi Teknik Informatika Universitas PGRI Madiun. Jurnal Nasional Pendidikan Teknik Informatika. Volume 8 Nomor 1, Halm. 81-86.

Sugiyono. 2013. Metode Penelitian Kombinasi (Mix Methods). Bandung: Alfabeta.

2017. Metode Penelitian Kombinasi (Mix Methods). Bandung: Alfabeta.

Undang-Undang Standar Nasional Pendidikan.

Warsito, Peran TIK dalam Penyelenggaraan PJJ. Jurnal Teknodik April 2007. No. 20: 941. Jakarta: Pustekkom depdiknas. 